\title{
The French Revolution and the Discourse of Change in Restoration France and Post-1815 England
}

Mathieu Robitaille, University of Victoria

\begin{abstract}
The conception of revolution was changed drastically by the French Revolution of 1789 from its original use in astronomy to imply a return to a previous state of being. Henceforth, revolution came to signify a drastic rupture with past practices. For French and English liberals in post-Napoleonic Europe, the word revolution also became loaded with negative connotations associated with the French Revolution's radical turn from 1792 to 1794, and the fear of popular violence. My paper examines and compares how the stigma associated with the French Revolution influenced the discourse of change in France and England, and how the fear of revolutionary violence influenced the actions of both governments.
\end{abstract}

\section{Introduction}

The late eighteenth and early nineteenth centuries were periods of sweeping change throughout Europe. Industrial changes, emanating from England, started to spread through Continental Europe, creating new socioeconomic conditions while the French Revolution and the Napoleonic Wars transformed Europe's political culture. 
For some, like Edmund Burke and Metternich, the French Revolution represented an evil that had to be stopped at all cost, while for others like Thomas Paine and Madame de Staël, the Revolution was but one step in the righteous direction of liberty and progress. While the Revolution's principles were championed by reformers and the advocates of liberal change throughout Europe, its excesses were reminders of the dire consequences of embracing radical change at the expense of tradition. Yet, as the period following the Congress of Vienna demonstrated, some political changes would nonetheless have to be made in order to appease the increasingly politically conscious populations of a multitude of European nations.

While a wider comparative approach including France's continental neighbors would undoubtedly be fruitful, this study will be limited to the comparison of the impact of lingering fears of the French Revolution in the political discourse of England and France. Several reasons have prompted me to undertake this research, the first being that in both nations the debates for and against a series of liberal political changes were taking place simultaneously. Moreover, the political system adopted in Restoration France and had much in common with that of England: Louis XVIII's executive power was to be limited by a constitution, and further tempered by a bi-cameral legislature composed of a lower and an upper chamber with powers of taxation. Furthermore, in both nations strikingly similar arguments were being made, with the play on the fear of disorder being central to the debates. Specifically, lingering fear of the French Revolution was 
used to obstruct liberal political change by equating the latter with violence and chaos. Proponents of political change in both nations had to circumvent charges from their opponents that change would lead to chaos. Once proponents of change in both nations had achieved the above, they were able to carry public opinion, which resulted in real change: the Three Glorious Days in France and the Great Reform Act of 1832 in England.

While the two nations had strikingly different political traditions, I will argue that as a precondition to liberal political change in the twenty years which followed the Congress of Vienna, proponents of change in France had to subdue public fears that the Revolutionary tradition was necessarily chaotic, while those in England were forced to exploit the fear of the Revolution to present reforms as the only way to avoid revolutionary disturbances. Although it is doubtful that leading experts on the period would disagree with this statement, much of the historiography of the Great Reform Act and the 1830 July Revolution in its current state does not give the political manipulation of the fear of legislators and the electorate its due importance. I intend to demonstrate that for both liberal and conservative politicians in France and England the manipulation of fear was an essential part of the debate concerning the increasing liberalization of politics. Such an analysis is timely in light of recent political developments, such as the criticism leveled on the American government and media for the 'fear mongering' and the constant reminders of the events of September $11^{\text {th }}, 2001$, in the lead-up to the launching of the 2003 invasion of Iraq. 
This brief survey of the period following the Congress of Vienna will largely draw from existing work from historians of both France and England. It is rather the emphasis on the fear of the French Revolution and its analogous impact in both France and England which will be the focus of my piece. The first section will outline the similarities and differences between the Liberal Opposition in France and the Reformers in England, as well as the political contexts in which both operated. The second section will analyze the place of the French Revolution in English political discourse from the 1790s until the Great Reform Act, focusing on the Reformers and their opponents in government. Finally, the third section will shift to the political discourse in France from the 1790s to the July Revolution of 1830, focusing on the Liberal Opposition and their opponents in government.

\section{Proponents of change in France and England}

The term proponents for change used above is an extremely, but intentionally, broad and ambiguous term. In France, the men who sought change are collectively called the Liberals or the Liberal Opposition by historians of the era. They were an extremely motley group and had little doctrinal coherence. This included the left, which was made up of Republicans and Bonapartists, and the centre-left, which was made up of Liberals and former members of the King's cabinet such as the Doctrinaires. The main principle which bound these men together was their efforts to develop the representative principle in the Charter, 
maximizing the political powers of the legislative at the expense of the King's executive power. ${ }^{1}$

Likewise, the proponents of change in England were composed of diverse elements. This group included Libertarians, Dissenters, Radicals, and parliamentary Whigs. Historians often refer to these groups collectively as Reformers. As in France, the many that made up these groups had conflicting political doctrines, but were united by certain principles. The most important unifier in the English case was their common effort to reform the parliamentary system to make it more representative. The main problem with an unreformed parliamentary system was its distribution of seats in the House of Commons and the limited number of English subjects who could vote. ${ }^{2}$

\section{Political contexts in France and England}

Despite the similarity of their main objective, which was to make their political systems more representative, there were crucial differences between the two nations' political and historical contexts which must be noted. In post-1815 England, the political settlement had long been stable and was accepted by an overwhelming majority of the population. The Glorious Revolution of 1688 had established a system which had since functioned effectively and few in England seriously considered its overthrow.

${ }^{1}$ Robert S. Alexander, Re-writing the French Revolutionary Tradition: Liberal Opposition and the Fall of the Bourbon Monarchy (Cambridge, New York: Cambridge University Press, 2003), 27.

2 Eric J. Evans, The Great reform Act of 1832 (London and New York: Methuen, 1983), 1-5. 
Even the most discontented among the Reformers sought to affect change by working within the political system. The use of popular disturbances was seen as a method of applying extra-parliamentary pressure on the government, rather than to precipitate a revolution. Furthermore, England's own revolutionary tradition bore little resemblance to that of France. In England, even after 1789, the term revolution was used in its original astronomical sense, which implied circularity. ${ }^{3}$ Politically, revolution was used to denote a return to a previous state of being. In the case of 1688 , the rhetoric which had largely been used in parliament was that the Stuarts were usurpers who had to be overthrown in order to restore the legitimate heirs to the Crown. The French Revolution did contribute to transforming the word into one which meant change, but the above meaning was never entirely lost. ${ }^{4}$

In fact, some historians have argued that the French Revolution's greatest impact in England was on the minds of the ruling elite rather than on Reformers. ${ }^{5}$ In the historiography of England's Reform movement, a major dividing line is whether the French Revolution contributed or was a hindrance to the Reform movement. ${ }^{6}$ Advocates of

3 George Woodcock, "The Meaning of Revolution in Britain, 1770-1800," in Ceri Crossley and Ian Small (eds), The French Revolution and British Culture (Oxford: Oxford University Press, 1989), 1-4.

${ }^{4}$ Ibid.

${ }^{5}$ An example can be found in John Stevenson, Popular Disturbances in England, 1700-1870 (London and New York: Longman, 1992), 136-137.

${ }^{6}$ For instance, historians like E.P. Thompson, in his classic The Making of the English Working Class (New York: Pantheon Books, 1964), have argued that the French Revolution put the Reform movement back for a generations, while historians such as Eric J. Evans in the above-cited work argued that the French Revolution is a major factor which contributed to the Reform era. 
the former view argue that the French Revolution changed the way in which nineteenth-century English society viewed politics and politicized the lower and working classes, creating the conditions necessary to convince the King and his parliament that reforms were the only way to avoid further disturbances.

Conversely, advocates of the latter view argue that |405 by convincing the English ruling classes that all political change necessarily led to chaos, the Reform movement, which predated the Revolution and was well under way prior to 1789 , was set back for more than a generation. While both interpretations have some elements of truth, I will argue that the French Revolution had a restraining impact on the Reform movement, and that it was not until the proponents of change learned to use the fear of the French Revolution to push for the necessity of Reform that the latter became possible. In other words, I will argue in the following section that the French Revolution held the Reform movement back until the 1820s, when it was used by Reformers to cultivate fear of the possible consequences of failing to reform England's political system.

In France, where the impact of the French Revolution and the Napoleonic Wars was much more direct than in England, the proponents of change fought to preserve the Revolution's gains. Louis XVIII had been installed as King by the Allied powers, and many old opponents of the Revolution were given influence in political matters. Whether Republican, Bonapartist, Liberal, or anyone who did not want to see a return to the Ancien Régime, the Restoration had the potential to be disastrous. 
Under the auspices of foreign governments, the Liberal Opposition hoped to use the Charter to prevent Royalists from "turning back the clock." The Charter, whose wording had been left ambiguous in some of its most important sections, was largely open to interpretation, out of which two major lines developed. ${ }^{7}$ The first interpretation, which was adopted by the Liberal Opposition, was that the Charter was essentially a contract between the King and the nation.

For the Liberal Opposition, the Charter was above the King, who was obligated to govern within its limits. This interpretation emphasized that ultimately the King's source of power was the nation, whose will it followed. The Charter's representative principle was thus fostered to ensure the above. The second major interpretation of the Charter was adopted by the Royalists, who depicted the Charter as essentially being a gift from the King that could be removed at will. For the Royalists, the ultimate source of power lay in the King rather than the nation. Consequently, many who embraced this view of the Charter sought to promote its representative elements only when it was directly beneficial to their cause, such as during the early years of the Restoration when the government sought to strike a balance between the Liberal Opposition and the Royalists.

France's Liberal Opposition faced an uphill battle: the only aspect of the government in Restoration France which bore the semblance of representation was the

${ }^{7}$ Alexander, 1.

Past Imperfect 15 [2009] | @ | ISSN 1711-053X | eISSN 1718-4487 
Chamber of Deputies, whose major strength was its power over taxation. Members of the House of Deputies were elected by an electorate selected using tax qualifications. Wealth was thus the ultimate political litmus test during the Restoration period. ${ }^{8}$ The King, who gladly adopted the highly centralized Napoleonic institutions, was endowed with vast executive powers, and was able to assign an unlimited number of new Peers in the upper House at will. This is not to argue that the electors were completely isolated from the rest of the population, but to point out that in order to affect legal changes, the Liberal Opposition had to be sensitive to their political interests.

Throughout the Restoration, two main Revolutionary traditions of change prevailed: one of argument and persuasion, and another of force and coercion. The former consisted of the Liberal Opposition's attempts to influence the electorate and the Chamber of Deputies, while the second was embodied by insurrectionary and conspiratorial groups like the Carbonari. ${ }^{9}$ I will argue here that there existed an inverse relationship between the public and electorate's support of the Liberal Opposition at times the insurrectionary tradition was adopted, and that this was largely related to fears that the chaos and disorder of the 1790s would be repeated.

To summarize briefly the above points, France and England both functioned within strikingly different political

\footnotetext{
8 Pamela M. Pilbeam, The Constitutional Monarchy in France, 1814-1848 (Harlow and New York: Longman, 2000), 9.

${ }_{9}^{9}$ Alexander, 7.
} 
and historical contexts, notwithstanding the similarity of France's system with that of England. Each had their own traditions of reform and revolution. In England, the political system was well-established and the proponents of change did not seek to overthrow it. In France, conversely, the political system was highly disputed partly due to the ambiguity of the Charter. Despite these differences, the proponents of change in both countries had to appease the public and politicians' fears that change would necessarily lead to disorder.

\section{The French revolution and reform in England's political discourse}

In England, the earliest and most influential condemnation of the French Revolution came from Edmund Burke in his infamous Reflections on the Revolution in France (1790). Reflections was spurred by Dr. Richard Price, a dissenting Minister who saw the French Revolution as a remedy for the deficiencies of the Glorious Revolution. According to Price, 1688's major shortcoming was the inadequacy of the political representation it established.10 Contrarily, for Burke, the French Revolution was the antithesis of 1688 rather than its logical conclusion, as it had taken power away from France's natural leaders and placed it into the hands of the masses, famously referred to by Burke as the "swinish multitude." The Glorious Revolution, unlike that of France, had allowed the natural

10 Woodcock, 18-21. 
order to prevail by institutionalizing its power. ${ }^{11}$ By allowing popular pressure to influence politics, the French Revolutionaries had signed their own death warrants, and Burke predicted that as a result of such a drastic departure from tradition, chaos and violence would inevitably follow. Once the Revolution turned radical with the trial of Louis XVI and the Terror, Burke appeared prophetic, and with the outbreak of war against France, a patriotic antiRevolutionary backlash was unleashed against Reformers. ${ }^{12}$

Many involved in the Reform movement had welcomed the French Revolution and corresponded actively with members of the French National Assembly. The result was that the conservative elite in England began indiscriminately to view Reformers as guilty through association. Reformers, who had previously been tolerated, were seen as unpatriotic agents of foreign oppression. ${ }^{13}$ Popular disturbances, which had previously been used by Reformers as a means of applying extra-parliamentary pressure on the government, were subsequently seen in the light of the French Revolution. Many of the conservative elite in England looked across the Channel in horror at the result of popular involvement in politics, and consequently, the lines were blurred between Reformer and revolutionary. ${ }^{14}$

11 Clive Emsley, "The Impact of the French Revolution on British Politics and Society," in Ceri Crossley and Ian Small (eds), The French Revolution and British Culture, 34-35.

12 Philip Anthony Brown discusses this in "Burke and the Reaction," in his The French Revolution in English History (London: Cass, 1965), 75-79.

13 Emsley, 39-42.

14 Evans, 20. 
While certain historians have argued that Burke's Reflections laid the foundations for British politics for the next hundred years, I think that it unquestionably did for the first two decades of the nineteenth-century England. ${ }^{15}$ Until the end of the Napoleonic Wars, reform was barely considered by England's elite. Reformers were essentially "muzzled" by government repression and the Reform movement's association with the French Revolution. ${ }^{16}$ This was noted by Samuel Romilly, a Reformer who wrote in 1807 that "the influence which the French Revolution has had over this nation has been unfavourable to them (plans of Reform). Among the higher orders it has produced a horror of every kind of innovation."17 In the few instances which brought reform to the fore, the proponents of change went to great lengths to disassociate themselves from the French Revolution. For instance, in a Parliamentary speech in 1809, Whig MP William Windham stressed that demands for reform were a result not of "metaphysical reasoning or grievances of theory," but rather pragmatic discontent fueled by taxes and government corruption. ${ }^{18}$

The attitude which developed among all but the most radical proponents of change in England in the twenty-five year period following the French Revolution is fundamental to an understanding of English attitudes

${ }^{15}$ Stephen Prickett, England and the French Revolution (Houndmills, Basingstoke, Hampshire: Macmillan Education, 1989), 20.

${ }^{16}$ John R. Dinwiddy, "English Radicals and the French Revolution, 1800-1850," in The French Revolution and the Creation of Modern political Culture, volume 3, The Transformation of political Culture 1789-1848, edited by Francois Furet and Mona Onouf (Oxford: Pergamon, 1989), 448.

17 Quoted from Brown, 165-166.

${ }^{18}$ Dinwiddy, 448. 
towards reform from 1815 to 1832 as it remained prevalent throughout the era. Reform was equated with violence and chaos, and in order not to be castigated as traitors, Reformers had to find ways to disassociate themselves from anything that bore a resemblance to Jacobinism. For instance, Reformers such as Francis Burdett, William Cobbett, and Henry Hunt all argued for change within a specifically English context, using specifically English justifications. Neither of the above three discussed the Rights of Man, but rather the Rights of Englishmen; voting was not necessarily a Natural Right for all mankind, but a right which had been granted to Englishmen via a fifteenth-century statute. Moreover, there was no talk of a complete overhaul of the political system, but rather of fulfilling practical demands to alter taxation and government corruption, which was identified as the Reformers' main source of discontent 19

Reformers like Major John Cartwright and Walter Fawkes also attacked the appropriateness of making the comparison between the French Revolution and English Reformers. According to Cartwright, the political tradition in England had long accustomed the mind of the vast majority of Englishmen to responsible political citizenship, and stood in sharp contrast with the France of 1789: "The national mind of France, when called to the great work of political regeneration, was in utter darkness, forming a complete contrast to the public mind of England." 20 The

\footnotetext{
19 Ibid.

20 John Cartwright, Six Letters to the Marquis of Tavistock, on a Reform of the Commons House of Parliament (London, 1812): 24. 
English had the Magna Carta and a Bill of Rights which dated back centuries, while the vast majority of the French had been ruled despotically for over a thousand years:

They had been governed by the sword, and only knew how to resist by violence. They had no law, no ancient constitution, no proud legacy of their forefathers, to appeal to. They were misled by metaphysics and imaginary good. We bow to the accumulated wisdom and experience of the ages. When they had curbed their old government, they had a new one to make; when we get rid of our "virtual representation," we shall fall into the old current, and feel ourselves at home again. ${ }^{21}$

In the first four years after the Congress of Vienna, these appeals were not as effective as the Reformers would have hoped, and few of the Tories in government were convinced. Evidently, there were some noteworthy exceptions to the Reformers' attempts to separate their efforts from the French Revolution. For instance, in 1817, a Secret Committee of the House of Common claimed to have unfolded a plot in 1817 to overthrow the government prior to the Spa Field demonstrations. It noted that "the intended insurrection assumed the symbols of the French Revolution; a committee of Public Safety consisting of 24, was agreed upon...a tri-coloured flag and cockades were actually prepared. The flag was openly carried and

21 Walter Fawkes, The Englishman's Manual; or, a Dialogue between a Tory and a Reformer (London, 1817), 76. 
displayed at the first meeting." 22 The riots gave rise to a series of repressive laws such as the suspension of Habeas Corpus. When Romilly complained that during the 1780 Gordon Riots the latter measure had not been adopted, the Solicitor-General Castlereagh replied that "in the year 1780, there was no plan to disorganize the state; that no clubs for revolutionary reform were on foot; no plans for the subversion of Church and State were ramified." 23

\section{The English government's response and the reformers' riposte}

The government's excessive response to perceived revolutionary threats and its use of force eventually helped the Reformers gain the support of public opinion. In 1819, at St. Peter's Fields in Lancashire, a crowd of up to eighty thousand met to demonstrate for parliamentary reform. While peaceful, the sheer size of the demonstration convinced local magistrates that it would degenerate into an insurrection, and orders were given to open fire. Eleven people were killed and four hundred injured. This event, which received tremendous publicity, was dubbed the "Peterloo Massacre" by the press, which attacked the government's actions as tyrannical. Radicals and Whigs in the House, while a minority, were also quick to criticize the authorities' response. ${ }^{24}$ Peterloo sparked a series of riots

${ }^{22}$ Cited in Lord Beloff, "The Impact of the French Revolution upon British Statecraft, 1789-1921," in Ceri Crossley and Ian Small, The French Revolution and British Culture, 88.

${ }^{23}$ Quoted from Stevenson, 197.

24 Ibid. 
and gave rise to the Six Acts, introduced to the House by Lord Sidmouth. The Acts were aimed at giving the government added strength when dealing with radical Reformers. When asked about their necessity, Lord Wellington remarked that "the Reformers were out to dispossess the gentry, and that it was vital to prevent them from getting arms at all cost." 25 Some historians see Peterloo as the catalyst that won over the House's aristocratic Whigs to the cause of the Reformers, while others see it as paving way for the 1820s in which the association between the Reform movement and revolution began to recede. The fear of the masses, however, pervaded through the era. ${ }^{26}$

After Peterloo, Reformers increasingly pointed to their opponents' propensity for using fear of the French Revolution to obstruct change. Lord John Russell wrote in 1820:

If a book is written containing opinions on subject of philosophy and literature, we are told to avoid them, for to Voltaire and Rousseau is to be ascribed the French Revolution. If an ignorant cobbler harangues a ragged mob in Smithfield, we are told that the state is in danger, for the fury of the mob was the beginning of the French Revolution. If there is discontent in the manufacturing towns, we are told that

25 Quoted from Stevenson, 216.

26 Norman McCord and Bill Purdue, in J. M. Roberts (ed), British History, 1815-

1914 (Oxford: Oxford University Press, 2007), 24-27. 
discontent of the manufacturing towns in France was the great cause of the French Revolution. Nay; even if it is proposed to allow a proprietor of land to shoot partridges and hares on his own ground, we are told that this would be to admit the doctrine of natural rights, the source of all the evils of the French Revolution. ${ }^{27}$

The awareness of the exaggerated nature of the threat of revolution contributed to changing the attitude of all but the most conservative of the English elite towards political change and its irremediable propensity for violence. Another likely factor for this "relaxing" was the improvement of Great Britain's economy, which reduced public disturbances in the early $1820 s .{ }^{28}$ Undoubtedly, the passage of time also contributed to a change in the English public's perception of the French Revolution, as some Reformers began a trend which was also discernible in France throughout this period: the separation of the "good" from the "bad" Revolution.

A great example of the above is from radical Reformer Richard Carlile. In a September 1819 addition of his The Republican journal, he published an article entitled "Benefits of the Revolution in France: Concerning which it is assumed few will disagree." The article listed a series of positive changes which resulted from the French Revolution, not least importantly "the establishment of a

27 Lord John Russell, Essays and Sketches of Life and Character. By a Gentleman who has left his Lodgings (London, 1820), 141-42.

28 Stevenson, 216-17. 
representation of the people; full, free and equalized a very high degree." 29 In his journal The Gorgon, radical John Wade wrote that despite the Revolution's radicalism and violent excesses, the results of the Revolution should be the criterion to judge it. Amongst the positives, Wade pointed to the economic, agricultural, infrastructural, and administrative advances made since the Revolution, as well as improvements in law and communications. The tithe, feudal dues, and noble privileges had been abolished, and as a result the entire nation was better off. 30

Others went much further, and attempted to "revise" the Burkean interpretation of the French Revolution. For instance, John Stuart Mill argued that the French Revolution was not inherently violent, and that its excessive phase was a direct result of the privileged orders' stubborn unwillingness to adjust to the progress of society. Mill's interpretation of the Revolution sympathized with the Girondins, whom he described as "the purest and most disinterested body of men, considered as a party, who ever figured in history." 31 The Revolution's crimes, according to Mill, were due to the Girondins' admirable attempt to defend the Revolution from "its irreconcilable enemies from within and from without."32 Likewise William Hazlitt, another proponent of reform, argued that the true cause of the Revolution's excesses was the Brunswick Manifesto, and interpreted the Terror as necessary to preserve the

${ }^{29}$ Quoted from Dinwiddy, 430.

30 Ibid.

31 Quoted from Dinwiddy, 430.

32 Ibid. 
Revolution's advances. Hazlitt was also a major admirer of the Girondins:

The true representatives of liberty, ... necessarily gave place to those men of violence and blood, who, rising out of the perilous situation in which the Republic was placed, were perhaps alone fitted, by their furious fanaticism and disregard of all ordinary feelings, to carry the Revolution triumphant through its difficulties, by opposing remorseless hatred to the cold-blooded and persevering efforts of tyranny without, and cruelty and the thirst of vengeance to treachery and malice within. ${ }^{33}$

In 1826, Hazlitt echoed the sentiments of most Reformers: "The cant about the horrors of the French Revolution is mere cant - everybody knows it to be so...There were none in the American, and have been none in the Spanish Revolution."34

\section{The "New Tories" and the commitment to oppose reform}

But despite the Reformers' attempt to separate the French Revolution's excesses from its positive results, it was the King and the leading "Tories" who needed convincing. From 1812 to 1827, Lord Liverpool was prime

33 Quoted from Dinwiddy, 431.

34 Ibid. 
minister. The term Tory, which has often been used to denote his government, is somewhat misleading as British party politics throughout this period were much more fluid than today. The founder of the "New Tory" party was William Pitt, who had considered himself an Independent Whig. Liverpool's Tories were more a coalition of different elements than a party, much like the Reformers. ${ }^{35}$ Moreover, Liverpool's government had little in common with the Tories of the eighteenth century who had advocated the divine right of Kings and passive obedience. As historian Frank O'Gorman put it, the New Tories were "in favour of the loyalism of the 1790s, the ideology of Burke, the wartime sacrifices of the Revolutionary and Napoleonic period, the defense of Protestantism and, not least, nostalgia for the towering figure of William Pitt."36 It is noteworthy that Pitt's famous break with Fox, which led to the foundation of New Toryism, was largely due their opposing view of the French Revolution.

Michael G. Brock, another renowned historian of the Reform movement, went as far as arguing that the only thing that held the Tories together during Liverpool's ministry was their opposition to reform, bred by lingering fears of the French Revolution. ${ }^{37}$ While the above may be an overstatement, it is true that throughout his ministry Liverpool and his Tories were the main bulwarks against reform. ${ }^{38}$ Liverpool deeply distrusted popular involvement

35 McCord and Purdue, 10-11.

36 Frank O' Gorman, The Long Eighteenth Century: British Political and Social History 1688-1832 (London: Arnold, 1997), 285.

37 Michael G. Brock, The Great Reform Act (London: Hutchinson, 1973), 65.

38 Ibid., 47. 
in politics, and revealed to Chateaubriand his fears that London, like Paris in 1789, may be defenseless in the case of popular insurgency as "one insurrection in London and all is lost." ${ }^{39}$ Most in his ministry were likeminded, and convinced to prevent any steps in the direction of revolution. For instance George Canning, the Foreign Secretary from 1822 to 1827, is well known for his resolve to oppose reform since the launch of his career when he was editor of the Anti-Jacobin periodical in 1797, which sought to alert the propertied classes of the dangers of reform. ${ }^{40}$ For most of the 1820 s, the Reformers continued to face a government which was hostile to reform. Liverpool, following his death, was briefly succeeded in 1827 by Canning, who in turn passed four months later. Canning was succeeded by Goderich in August 1827, who was then replaced by lord Wellington in January 1828.

\section{Reformers, the language of menace, and the Three Glorious Days}

The Tories' continued opposition to the bulk of the Reformers' demands, and most importantly on the issue of electoral reform, led the latter to adopt new methods. The most important amongst these was "the language of menace," adopted by the likes of James Mill, Francis Place, and Joseph Parkes. The new method entailed conducting orderly, non-violent, and well-organized mass demonstration in order to protest the government's

${ }^{39}$ Quoted from Stevenson, 163.

40 Evan, 21-22. 
intransigence. The key was to convince the authorities that the demonstrators were ready to break out into destructive riots at any given point, without ever actually breaking out. ${ }^{41}$ In other words, Reformers sought to threaten the authorities with the use of force in order to generate fear of the consequences of continued opposition to reform. Their rationale was that surely the government would consider peaceful, government-instituted reforms a better option than armed revolution. Although this method did not initially yield any concessions from the Tories, it is nonetheless an important turning point because many important proponents of change argued that reforms were necessary to preserve the existing system. Simply put, it was not reform which would bring about the chaos and disorder deplored by the Tories, but rather the continued opposition to reform.

In late July 1830, news of the Revolution in France reached England. The impact of the Revolution provided a great spur for Reformers. Importantly, it demonstrated to many who had heretofore opposed reform that political change did not necessarily lead to anarchy. ${ }^{42}$ Wellington, however, was not one of those whom the relatively peaceful July Revolution had converted into a Reformer. Conversely, it strengthened his resolve to continued opposition to reform. Shortly after the Revolution, when he was asked about the Three Glorious Days, he noted that the first few months of Revolution in 1789 had also been

\footnotetext{
41 Stevenson, 218-29.

42 Roland Quinault, "The French Revolution of 1830 and Parliamentary Reform," History 79 (1994): 377-393. 
peaceful. ${ }^{43}$ Wellington's unflinching opposition stood in sharp contrast with the majority of public opinion in England and undoubtedly contributed to the sharp decline in his popularity which marked the remainder of 1830. In October 1830, Robert Peel remarked:

The success of the mobs and either the | 421 unwillingness or inability of the soldiers to cope with them in Paris and Brussels, is producing its natural effect in the manufacturing districts here, calling into action the almost forgotten radicals of 1817 and 1819 and provoking a discussion upon the probable results of insurrectionary movements in this country. ${ }^{4}$

By November, many Tories acknowledged that the leading mood in the country was now in favor of moderate reforms. But despite his party's recognition, Wellington continued to stand firm in his opposition, arguing that "beginning reform was beginning revolution." 45 Increasing popular disturbances, which peaked in November 1830, led to Wellington's resignation on November 16, which subsequently led to the King's designation of Lord Grey as head of government, with a specific mandate for moderate reform. Discussing his mandate with the Lords shortly after

\footnotetext{
43 Ibid, 383.

${ }^{44}$ Quoted from Quinault, 384.

45 Ibid., 384-85.
} 
taking office, Grey explained that "the principle of my reform is to prevent revolution." 46

\section{The Great Reform Act and fear}

While most historians agree that the King's designation of Lord Grey as prime minister made at least some major reforms inevitable, it is noteworthy that fear continued to play a central role in the debates on reform which raged on for almost two years. The most successful and famous Reformer who continued to "play the fear card" was Thomas Babington Macaulay. As early as 1827, Macaulay argued that within the English middle class, a factious spirit not unlike that of the Jacobins was developing and that unless moderates came to replace some of the "Tory reactionaries," England would undoubtedly suffer the same fate as France in $1789 .{ }^{47}$ In his first speech to the House of Commons in favor of reform, Macauley argued that France should be looked at as a model to avoid disorder, and gave the following explanation of the causes of the French Revolution:

A portion of the community which had been of no account expands and becomes strong. It demands a place in the system, suited, not to its former weakness, but to its present power. If this

46 Ibid., 392.

47 John Clive, "Macaulay and the French Revolution," in The French Revolution and British Culture, edited by Ceri Crossley and Ian Small (oxford University Press, 1989), 104.

Past Imperfect 
is granted, all is well. If this is refused, then comes the struggle between the young energy of one class and the ancient privilege of another. ${ }^{48}$

Was England's political situation not a direct parallel to that of France in $1789 ?$

It was because the French aristocracy resisted reform in 1783 that they were unable to resist revolution in 1789 . It was because they clung too long to odious exemptions, and distinctions, that they were at last unable to save their lands, their mansions, and their heads. They would not endure Turgot; and they had to endure Robespierre. ${ }^{49}$

Macaulay thus painted a picture of a thriving aristocracy not unlike that in England, whose stubbornness had proven to be its own downfall. He argued that this happened "because they had no sympathy with the people, no discernment of the signs of their time...because they refused all concession till the time had arrived when no concessions could avail."50 Macaulay reassured that it was not too late in Britain to prevent such a tragedy.

The Great Reform Act passed through the House of Commons and the House of Lords in 1832 effectively increased the size of the electorate to approximately 1 in 5

48 Quoted from Clive, 105

49 Ibid.

50 Ibid. 
adult males and redistributed the seats to give many manufacturing districts representation. My rendition of the Reform movement did not touch many other important factors which led to the Great Reform Act. I focused only on the impact of fear in the discourse which guided Reformers and their opponents in government in order to demonstrate the consistent use of fear in post-1815 English politics. To summarize, reform in 1815 continued to be guided by the ideology which developed largely from Burke's reaction to the French Revolution. From 1815 to 1819, the political elite in England equated reform with revolution. Consequently, British Reformers sought to clearly distinguish themselves from the French Revolution.

Peterloo was a major turning point which turned many former opponents of reform into supporters. Going forward from 1819, the fear of French influence diminished and Reformers willingly associated themselves with the French Revolution. Many of them sought to justify the Revolution's excesses and pointed to its benefits. Unable to dispel the fears of many of the leading Tories, Reformers attempted to appeal to the Tories' fears of revolution to justify reform. Even after the July Revolution in France, Reformers like Macauley continued to play on the elite's fear of the French Revolution to convince their opponents that reform was the only way to avoid the destructive path followed by France. It is not my argument that the French Revolution was responsible for the Great Reform Act, but that from 1815 to 1832, political change gave rise to fears among England's political elite which had to be cultivated by Reformers in order to make political change acceptable. 


\section{The French Revolution in political discourse: Opponents and Proponents}

As is well-known, the French Revolution was also opposed in France from the outset. The most vocal opponents were the émigrés who were composed of a wide variety of the discontented groups such as the nobility and the clergy. Opponents of the Revolution had also written their share of literature attacking its principles and making a direct link between the process of political change and violent episodes such as the Terror. ${ }^{51}$ Two of the leading counter-revolutionary writers in France were Joseph de Maistre and Louis de Bonald. Maistres' Considerations sur la France (1796) and Bonald's Theorie du pouvoir politique et religieux (1796) denounced the Revolution's attempt to impose change on France. They argued against the Revolution using religious language, depicting it as a satanic enterprise whose violent consequences proved God's displeasure. Both idealized the Ancien Régime's hierarchical structure and mourned the dissolution of the old privileged orders.

Like Burke, both thought the Revolution was inherently chaotic and they attacked its principles as necessarily leading to horrors like the Terror. The process of enacting such political changes went against God's will, and to avoid another bloodbath in the future, France had to restore the ideal political state which was unjustly

51 Pilbeam, "Revolution, Restoration, and Beyond: Changes, Continuities and the Enduring Legacies of 1789," in Martin S. Alexander (ed), French History since Napoleon (London: Arnold, 1999), 38-39. 
destroyed by the Revolutionaries. ${ }^{52}$ While Bonald and de Maistre did not hold the same sway among France's political elite as Burke did in England, their counterrevolutionary arguments were largely adopted by the Ultraroyalists and thus shaped the political discourse throughout the Restoration. For many in France who had embraced the changes brought forth by the Revolution and sought to preserve of it what they could, the Ultraroyalist threat was real.

Madame de Staël, one of the most influential French political thinkers of the era, was an avid defender of the Revolution, a proponent of liberalism, and an opponent of the Ultras. Largely viewed as a Liberal, Staël had embraced the Revolution's principles while condemning its atrocities. ${ }^{53}$ She viewed the Revolution as largely the work of the privileged who wanted to establish an English styled constitutional monarchy with a representative chamber. By turning against the Revolution and resisting the tide of change, it was the nobility who had doomed the Revolution's prospects for remaining orderly. For Staël, the emigration of thousands of the privileged meant the loss of the nation's conservative elements and allowed the disorderly proponents of egalitarianism and democracy to take over. The fundamental point of Staël's argument was that the Revolution's goals and principles were not to blame for the disorder which ensued, but that it was the elite's abandonment of the Revolution they had started. If only the Revolution had been guided by a politically

52 Robert Tomb, France 1814-1914 (London, New York: Longman, 1996), 27.

53 Louis Girard, Les libéraux français (Paris: Aubier 1985), 35-39. 
trustworthy and responsible group, the transition would have been smooth. ${ }^{54}$

Benjamin Constant is another highly influential member of the Liberal Opposition who sought to preserve the Revolution's gains. Like Staël, Constant disavowed any connection between the Revolution's principles and the Terror. As early as 1797, he wrote: "Let us separate then, in the history of the Revolutionary period, that which is part of the government, those measures which they had a right to take, from those crimes they committed and which they did not have the right to commit." ${ }^{55}$ Looking back on his denouncement of the Terror in 1829, Constant wrote:

I would not have recalled any memories of the Terror, but I thought it important for the future of France that she not confuse what is worthy of admiration and what is worthy of horror. To justify the reign of '93, to picture its crimes and frenzies as a necessity that weighs inevitably upon peoples when they seek freedom, is to harm a sacred cause, to do it more damage than its most avowed enemies. ${ }^{56}$

For Constant, the Terror was a political liability from which the Liberal Opposition had to disassociate itself. The Terror was not the inevitable result of political change, but

54 Ibid.

55 Quoted from Stanley Mellon, The Political uses of History: a Study of Historians in the French Restoration (Stanford: Stanford University Press, 1958), 22.

56 Ibid., 23. 
rather an aberration which needed to be distinguished from the positive aspects of the Revolution.

Constant, unlike Staël, did not insist on a specific form of government, and thought that any whose chief objective was the promotion of liberty was acceptable. Whether constitutional monarchy or republic, Constant was happy as long as liberty prevailed. Despite this doctrinal flexibility, Constant was not a supporter of democracy, and like Staël thought that the granting of universal suffrage would result in an attack on property and possibly anarchy. He thought that the state of politics should not surpass that of the maturity of the nation. While Constant hoped that one day the whole of society would gain the necessary education to exercise their political rights responsibly and independently, for the present, he thought that a limited electorate was the safest approach. ${ }^{57}$

\section{Insurrection and its failure}

But despite these misgivings about popular involvement in politics, Constant, like many other Liberals, was willing to wink at conspiratorial groups and associates who joined them, such as Lafayette, indicating his willingness to accept the results should insurrectionary methods prove successful. The sometimes conflicting aspects of Constant's politics are symptomatic of the diversity and fluidity of the Liberal Opposition, who often shifted tactics in their fight to preserve the Revolution's

57 Girard, 44-52. 
gains. Constant, like the many others in the Liberal Opposition who publicly refuted insurrectionary and conspiratorial methods but failed to condemn or distance themselves from it, contributed to the overwhelming political defeat of the Liberals at the hands of Villèle and the Ultras (to which we will return). ${ }^{58}$

Amongst the members of the Liberal Opposition willing to undertake armed revolt when argument and persuasion seemed to be failing, none was more famous than the Marquis de Lafayette. As a long-time supporter of republican principles, Lafayette's brand of liberalism stood in sharp contrast to that of many other politicians of the Liberal Opposition. While later becoming one of the leaders of the Carbonarist revolts, the Marquis understood the disadvantage faced by those willing to take arms against the regime:

The whole peasantry of the nation, the inferior classes of the towns, excepting a few departments are unanimous in their hatred of foreign influence... But the excesses of the Revolution have been so abominable that although the energies of the people are not inferior to those of 1789 , and their sense of their rights much more distinct, the existing abuses and designs of the privileged tribes find a great

58 Robert S. Alexander, 143-44.

Past Imperfect 
auxiliary in the general fear of another Revolutionary tempest. 59

The Carbonari may have been a failure and a political disaster for the Liberal Opposition, but it was nonetheless an extremely important "wing" of the Liberal Opposition in the early 1820s. The movement included some sixty thousand members, many of them as wellknown and respected as Lafayette. 60 Though far from a Jacobin, Lafayette held the majority of the people as capable of intelligently participating in politics, unlike many other Liberals. For Lafayette, fear of further Revolutionary disorder was a major restraint to establishing a political system conducive to his ideals.

\section{The Doctrinaires and the Revolution}

At the other end of the "Liberal spectrum" stood the Doctrinaires, who until Decazes' fall in 1820, sought to preserve the Revolution's gains from within the government rather than taking part in opposing the latter. Formed by such men as François Guizot, Barante, Charles de Rémusat, and Pierre Paul Royer-Collard, the Doctrinaires viewed the French Revolution like many other Liberals such as Constant and Staël. They embraced the Revolution's goals while repudiating revolutionary means. Guizot, who

${ }^{59}$ Quoted from Silvia Neely, Lafayette and the Liberal Ideal, 1814-1824: Politics and Conspiracy in an Age of Reaction (Carbondale: Southern Illinois University Press, 1991), 68.

60 Tombs, 340 . 
spent time as a history professor at the Sorbonne, wrote several histories of the French Revolution, portraying it as the culmination of a long-term secular evolution leading towards progress, reason, and the preponderance of the middle classes. 61

In 1821, Guizot complained of the government's continued use of fear to influence the electorate. The reason that "scare tactics" were effective, according to Guizot, was because many continued to portray the Revolution en bloc: "Do you realize that it is most dangerous to curse the Revolution in its entirety, and not to allow one to discriminate between good and evil, between sound principles and errors, between excellent results and deplorable straddling." 62 Likewise, Royer-Collard proclaimed in 1817: "This new nation....innocent of the Revolution from which it was born but which was not its own work, does not condemn itself to embrace or reject it in its entirety; its results alone is what the nation has embraced, free from all that made the Revolution deplorable." 63 Rémusat, the youngest member of the Doctrinaires, thought much along the same lines:

The Terror was very detrimental to the Revolution: it stopped the Revolution's march forward and made it retrograde, yet some people

61 Girard, 69-71.

62 Quoted from Mellon, 23.

63 Quoted from Girard, 72. My own translation from French: "cette nouvelle nation...innocente de la Révolution dont elle est née, mais qui n'est point son ouvrage; elle ne se condamne point à l'admettre ou à la rejeter toute entière; ses résultats seuls lui appartiennent, dégagés de tout ce qui les a rendus irrévocables." 
think of the Terror as necessary: a dangerously false idea, as the Terror was an accident. Its causes were circumstances and not the inevitable spirit of the times. ${ }^{64}$

The Terror was an accident, not an historical inevitability and had to be separated from the rest of the Revolution. While sharing a similar historical interpretation as many others in the Liberal Opposition, the Doctrinaires stood apart from the Liberal Opposition, often acting as a 'third party' during the Decazes era. The Doctrinaires were willing to strike a balance between the Liberals and the Ultras, often compromising central Liberal goals in the process. ${ }^{65}$ Once purged from the government, the Doctrinaires were glad to reconcile themselves with the Liberal Opposition.

My analysis has focused on how influential members of the Liberal Opposition interpreted the Revolution and assessed its impact on Restoration politics. It is important to note that while several members of the Liberal Opposition held very different political doctrines, common points could be discerned in their interpretation of the Revolution. Staël, Constant, Lafayette and the Doctrinaires all thought it necessary to demonstrate that the fears of embracing the Revolution's principles were unfounded, and

64 Ibid., 72-73. My own translation from French: "La Terreur fut très funeste à la Révolution. Elle en arrêta la marche, elle la fit rétrograder, il y a pourtant des gens qui croient qu'elle en était la suite nécessaire : idée fausse et dangereuse, c'est bien la Terreur au contraire qui fut un accident. Elle eu pour cause des circonstance qui aurait pu ne pas se rencontrer et non l'esprit du siècle qui ne pouvait ne pas être."

65 Robert S. Alexander, 28. 
all went to great lengths to demonstrate that the apprehension of change was engendered by a misinterpretation of the Revolution. Staël, Constant and the Doctrinaires thus wrote extensively to disprove the idea that the Revolution's degeneration into violence was inevitable, and argued that it was the product of specific circumstances. As historian Stanley Mellon pointed out, history in the Restoration was a function of politics. ${ }^{66}$ The Liberal Opposition were well aware that to save some of the Revolution's gains, they would have to reshape France's collective memory. By attempting to separate the "good" from the "bad" in the Revolution, members of the Liberal Opposition sought to preserve its legacy and to dispel the fears it engendered.

\section{Turning the tables: the Liberal Opposition's manipulation of fear to promote change}

It was not the changes brought about by the French Revolution which scared the electorate and the general public in France, but the methods used in order to effect change. The Liberal Opposition's strategy thus turned to convincing the electorate and the public that their political agenda would not inevitably lead to a return to disorder or a repeat of the Terror. ${ }^{67}$ In order to demonstrate that the Liberal Opposition's apprehension of the disorder associated with the Revolution's legacy was well-founded, the following section will analyse the two great political

66 Mellon, 1.

${ }^{67}$ Robert S. Alexander, passim. 
crises of the Restoration period, the Liberal Opposition's tactics throughout, and the result each yielded.

The first of the great crises of the era was precipitated by the Liberals' resistance to the Decazes government's proposal to revise the Lainé Law. ${ }^{68}$ For many Liberals, the Law was a clear violation of the Charter, and a decisive step towards the re-establishment of the Ancien Régime. This apprehension gave rise to conspiratorial and insurrectionary attempts to overthrow the Bourbons. Consequently, from 1820 to 1824, Richelieu and Villèle were able to use the public's fear of insurrections to undertake a series of repressive acts like strict press control, which allowed the ministry a large degree of control over public opinion. Moreover, throughout the period, Villèle's government took the opportunity to enact a series of purges aimed at ousting potential Liberal opponents and controlling the electorate by eliminating voters of Liberal leanings. These despotic measures subsequently allowed for the destruction of grassroots associations key to the Liberal Opposition's cultivation of public opinion. ${ }^{69}$

The public allowed this reactionary assault to proceed largely because of their fear of supporting Liberals. The crisis had polarized politics in France as the Liberals' willingness to conspire or tolerate conspiracy had alienated potential allies in the centre. While the vast majority had continued to adhere to the legal means of enacting change, the Liberal Opposition's ambivalence or silence over the

68 Ibid., 333.

69 Ibid., 144-159.

Past Imperfect 15 [2009] | (C) | ISSN 1711-053X | eISSN 1718-4487 
insurrections led many to see them as guilty through association. ${ }^{70}$ After all, well-known and influential Liberals such as Lafayette, d'Argenson, Jacques-Antoine Manuel, and Jacques Koechlin had all been involved with the Carbonarists, while politicians like Guizot, Sébastien Foy, and Casimir Périer had defended Carbonari Deputies in the Chamber. ${ }^{71}$ Charles Goyet, condemning the Carbonarists' ineffectiveness in bringing about change, proclaimed in 1821 that "those who wish the ends wish the means. I would say to those who have not wanted the means that they have not wanted the ends." 72 For Goyet, the Carbonarists had repudiated the Liberals' goals by deviating from legal resistance. The four-year period following the fall of the Decazes government was thus disastrous for the Liberal Opposition. The result of the election of March 1824, in which the Royalists won 410 seats and the Liberals only 19, demonstrates how unpopular the Liberal Opposition had become directly following the insurrectionary attempts of the Carbonari. ${ }^{73}$

The Liberals' crushing electoral defeat of 1824 stands in sharp contrast with their overwhelming gains in the elections of 1827 to 1828, showing a change of context. Louis XVIII's successor, Charles X, was the leader of the Ultras and was vital in the passage of the Indemnification Bill and the Law of Sacrilege. Also, an unsuccessful attempt was made to reinstate primogeniture and many Liberals

\footnotetext{
70 Ibid., 167.

71 Ibid., 144.

72 Quoted from Robert S. Alexander, 186.

73 Tombs, 341.
} 
realized that they had to form a broad coalition of all those discontented with the government in order to halt further reactionary measures. From 1825 the Liberal Opposition put their efforts into effecting change exclusively using legal means. The new posture adopted by the Liberals was one which claimed loyalty to the King, while denouncing "bad influences" in the Chamber and in his ministry. ${ }^{74}$ Through the foundation of such groups as Aidetoi, le ciel t'aidera, Liberals raised awareness of the importance of opposing the Villèle ministry and helped with voter registration while convincing moderates that they were not revolutionaries. ${ }^{75}$ In November1828, when Louis Cauchois-Lemaire called for an armed revolt headed by the Duke d'Orlean, Liberals scorned him for embracing methods conducive to the rejuvenation of Royalist unity. ${ }^{76}$

The success of the Liberal Opposition's drive to halt the government's reactionary measures is well documented, but few give the Liberals their due credit. Some historians, like Pamela Pilbeam, have pointed to the fact that many Liberals such as Casimir Périer and Jacques Lafitte were present in Paris throughout the Three Glorious Days, but stayed hidden in their homes. Pilbeam largely credits the Paris artisans for precipitating Charles X's abdication. ${ }^{77}$ While it is true that Liberals didn't actually participate in the Revolutionary fighting, Pilbeam's approach tends to

\footnotetext{
74 Robert S. Alexander, 200-02.

75 Ibid., 211-18

76 Ibid., 237.

77 Pilbeam, The French Revolution of 1830 (New York: St. Martin's Press, 1991), 64-65.
} 
undermine the importance of the Liberal Opposition's effort to turn public opinion in favour of political change and to cultivate widespread opposition to Charles $\mathrm{X}^{\prime}$ government.

Rather than being 'mere spectators' to the July Revolution, the Liberal Opposition should be seen as laying the groundwork necessary for making the Revolution acceptable to the majority of the French public. What truly made the difference between the Carbonarist revolts of the early 1820 s and the July Revolution was not the Paris artisans' participation in the latter, but rather the Liberal Opposition's ability to persuade the vast majority in France that change was absolutely necessary and would not lead to disorder. By adopting peaceful, legal means and persuading public opinion that the government was the main threat, the Liberals effectively dispelled the public's fears to support a Liberal agenda and rather portrayed the government's reactionary measures as likely to lead to another period of disorder. In other words, it was not the Liberal Opposition's principles or goals which had changed throughout the 1820s, but the means which they used to attain these goals. ${ }^{78}$ The legal revolutionary tradition of argument and persuasion successfully dispelled the fears of chaos which lingered from the Terror, a necessary prerequisite to the acceptance of a Liberal political programme.

78 Robert S. Alexander, 334-35.

Past Imperfect 


\section{Conclusion}

Many striking political parallels can be discerned in France and England in the period after the Congress of Vienna. In both nations, a coalition of men emerged to develop their respective political system in order to make it more representative. Each coalition faced stiff resistance from opponents of change in government and of the main obstacles to gaining mass support in both cases, fear stemming from the violence associated with the French Revolution was at the forefront. In England, attempts by reformers to dispel the fear of political change by recasting the Revolution were too little and to no avail. Instead of attempting to surmount the English political elite's fears, the Reformers thus sought to exploit them, and portrayed reform as being England's only hope to avoid their own French Revolution. In France, the Liberal Opposition had to separate the Revolution from the Terror. The writing of history was one of the ways which allowed the Liberals to defend the Revolution's principles and gains. When the latter were threatened, the Liberal Opposition's willingness to embrace an insurrectionary Revolutionary tradition alienated them from moderates and the public. This led the Liberal Opposition to abandon the insurrectionary tradition in favour of legal arguments and persuasion. By following legal means, the Liberals were able to dispel the fears of disorder, which allowed for the establishment of the July Monarchy. The main common denominator in both nations, I have argued, was the use of fear in shaping the discourse of political change. 


\section{Bibliography}

Alexander, Robert S. Re-writing the French Revolutionary Tradition: Liberal Oppositionand the Fall of the Bourbon Monarchy. Cambridge, New York: Cambridge University Press, 2003.

Brock, Michael G. The Great Reform Act. London: Hutchinson, 1973.

Brown, Philip Anthony. The French Revolution in English History. London: Cass, 1965.

Cartwright, John. Six Letters to the Marquis of Tavistock, on a Reform of the Commons House of Parliament. London, 1812.

Crossley, Ceri, and Ian Small, eds. The French Revolution and British Culture. Oxford: Oxford University Press, 1989

Dinwiddy, John R. "English Radicals and the French Revolution, 1800-1850," in Francois Furet and Mona Onouf (eds), The French Revolution and the Creation of Modern political Culture, volume 3, The Transformation of political Culture 1789-1848. Oxford: Pergamon, 1989.

Evans, Eric J. The Great reform Act of 1832. London and New York: Methuen, 1983. 
Fawkes, Walter. The Englishman's Manual; or, a Dialogue between a Tory and a Reformer. London, 1817.

Girard, Louis. Les libéraux français. Paris: Aubier, 1985.

McCord, Norman, and Bill Purdue in Roberts. J. M. (ed), British History, 1815-1914. Oxford: Oxford University Press, |440 2007.

Mellon, Stanley. The Political uses of History: a Study of Historians in the French Restoration. Stanford: Stanford University Press, 1958.

Neely, Silvia. Lafayette and the Liberal Ideal, 1814-1824: Politics and Conspiracy in an Age of Reaction. Carbondale: Southern Illinois University Press, 1991.

O'Gorman, Frank. The Long Eighteenth Century: British Political and Social History 1688-1832. London: Arnold, 1997.

Pilbeam, Pamela M. "Revolution, Restoration, and Beyond: Changes, Continuities and the Enduring Legacies of 1789," in Martin S. Alexander (ed), French History since Napoleon. London: Arnold, 1999.

Pilbeam, Pamela M. The Constitutional Monarchy in France, 1814-1848. Harlow, New York: Longman, 2000. 
Pilbeam, Pamela M. The French Revolution of 1830. New York: St. Martin's Press, 1991.

Prickett, Stephen. England and the French Revolution. Houndmills, Basingstoke, Hampshire: Macmillan Education, 1989.

Quinault, Roland. "The French Revolution of 1830 and Parliamentary Reform," History 79 (1994): 377-393.

Russell, John. Essays and Sketches of Life and Character. By a Gentleman who has left his Lodgings. London, 1820.

Stevenson, John. Popular Disturbances in England, 17001870. London, New York: Longman, 1992.

Thompson, E.P. The Making of the English Working Class. New York: Pantheon Books, 1964.

Tombs, Robert. France 1814-1914. London and New York: Longman, 1996. 